\title{
Application of sharing genetic algorithm for optimization of groundwater management problems in Wadi El-Farigh, Egypt
}

\author{
M. I. GAD - S. Khalaf
}

Received: 10 February 2013/Accepted: 30 May 2013/Published online: 25 June 2013

(c) The Author(s) 2013. This article is published with open access at Springerlink.com

\begin{abstract}
Management of groundwater resources is very important for regions where freshwater supply is naturally limited. Long-term planning of groundwater usage requires method-based new decision support tools. These tools must be able to predict the change in the groundwater storage with sufficient accuracy and must allow exploring management scenarios with respect to different criteria such as sustainability and cost. So, a multi-objective optimization algorithm is used for groundwater management problem. In this paper, a genetic algorithm (GA) with two additional techniques, Pareto optimality ranking and fitness sharing, was applied to simultaneously maximize the pumping rate and minimize pumping cost. The methodology proposed herein has more Pareto optimal solutions, however, it is desirable to find the ones scattered uniformly over the Pareto frontier to provide a variety of compromise solutions to the decision maker. A groundwater resources management model is performed through a combined simulation-optimization model. This model is called the multi-objective genetic algorithm (MOGA) for optimization which combines the MODFLOW and GA. MOGA model applied in Wadi El-Farigh, Egypt, to develop the maximum pumping rate and minimum operation cost as well as to predict the future changes in both pumping rate and pumping operation cost. Model makes a feasible solution in groundwater management. Finally a
\end{abstract}

M. I. GAD

Hydrology Department, Desert Research Center, Cairo, Egypt

S. Khalaf $(\square)$

Irrigation and Hydraulics Department, Faculty of Engineering, Mansoura University, Mansoura, Egypt

e-mail: samykhalaf2005@yahoo.com compromise solution is presented from a set of Pareto optimal solutions to help the decision maker.

Keywords Groundwater management - Multi-objective optimization · Fitness sharing - Genetic algorithm · Wadi El-Farigh · Egypt

\section{Introduction}

Optimization is a procedure of finding and comparing feasible solutions until no better solution can be found. Solutions are termed good or bad in terms of an objective, which is often the maximization of total pumping from an aquifer, minimization of the total pumping cost to satisfy the given demand, efficiency of irrigation, or other factors (Moharram et al. 2011). The presence of multiple conflicting objectives is natural in many groundwater management problems and makes the optimization problem interesting to solve. Since no one solution can be termed as an optimum solution to multiple conflicting objectives, the resulting multi-objective optimization problem resorts to a number of trade-off optimal solutions. Classical optimization methods can at best find one solution in one simulation run, thereby making those methods inconvenient to solve multi-objective optimization problems (Deb 2001).

Genetic algorithm (GA), on the other hand, can find multiple optimal solutions in one single simulation run due to their population approach. Thus, GAs are ideal candidates for solving multi-objective optimization groundwater problems. There usually exist a set of solutions for the multiple-objective case which cannot simply be compared with each other. For such solutions called Pareto optimal solutions, no improvement in any objective function is possible without sacrificing at least one of the other 
objective functions (Reading et al. 1987; Cheng and Gen 1998).

Compromise solution-based fitness assignment has been proposed by Cheng and Gen (1998) as a means to obtain a compromised solution instead of generating all Pareto optimal solutions. For many problems, a set of Pareto solutions may be very large. Having to evaluate a large set of Pareto solutions to select the best one poses a considerable cognitive burden on the decision maker. Groundwater simulation and optimization techniques have been used together to explore management options. Depending on the particular problem under consideration and the assumptions made in solving it, the optimization problem may be deterministic, stochastic, or a combination of both. Shafike et al. (1992) used quadratic programming to study pumping costs with drawdown, when drawdown magnitude exceeds a small fraction of the saturated thickness. Hsiao and Chang (2002) presented optimization required in a broad range of design problems for fixed costs of installing new wells may be a relevant component of cost functions in groundwater planning strategies. Hsu and Yeh (1989) studied the monitoring network design and several groundwater remediation design projects gave rise to combinatorial problems in which decision variables include location of wells and pumping rates. Ahlfeld and Heidari (1994) studied hydrogeological complex sites in which conditions obscure an obvious intuitive design; simulation-optimization techniques help decision makers in shedding light over alternate feasible options.

Park and Aral (2003) presented a multi-objective optimization approach to determine pumping rates and well locations to prevent saltwater intrusion, while satisfying desired extraction rates in coastal aquifers. This approach was an iterative sub-domain method, in which the proposed algorithm searches for the optimal solution by disturbing the well locations and pumping rates simultaneously. Frind (1982) studied two important objectives that were associated with the management of groundwater extraction in coastal aquifers. Ritzel et al. (1994) applied two variations of the genetic algorithm (GA), a Pareto GA and a vectorevaluated genetic algorithm (VEGA), for a multi-objective, groundwater pollution containment problem. The multiobjective problem was formulated to minimize the containment design cost while maximizing the design's reliability. The Pareto GA is based on a ranking scheme that ordered the population according to each containment design's degree of domination. The VEGA searches for multiple solutions for multi-objective problems simultaneously by selecting a fraction of the next population, based on the associated values of each objective function. Richardson et al. (1989) considered the VEGA as a multiobjective optimization method and reported that VEGA tended to favor the extrema of the objective functions, such that only the endpoints of the tradeoff curve were found. Ritzel et al. (1994) also concluded that the Pareto GA was superior to the VEGA in finding the largest portion of the Pareto optimal solutions. Cieniawski et al. (1995) investigated the performance of four GA formulations in solving a multi-objective groundwater monitoring problem where they simultaneously maximized reliability of a monitoring system and minimized the contaminant plume size at time of first detection. They implemented a weighted GA, VEGA, Pareto GA and a VEGA/Pareto GA combination and compared them to the results generated by simulated annealing. The VEGA/Pareto GA method was showed to be more computationally efficient and more successful at generating the greatest portion of the tradeoff curve than the other GA formulations. Goldberg (1989) recommended a form of fitness sharing to enhance the Pareto GA in this area, where crowding in the Pareto optimal solutions are alleviated by decreasing the fitness of crowded individuals. For multi-objective optimization methods, some modifications to simple GA have been made: multi-objective genetic algorithm (MOGA) (Saafan et al. 2011; Fonseca and Fleming 1993), VEGA (Schaffer 1985), niched Pareto genetic algorithm (Horn et al. 1994) and non-dominated sorting genetic algorithm (Srinivas and Deb 1994). The main advantage of the MOGA model is the possibility of linkage of the GA-based optimization model with an external flow simulation model. This model solves the complex groundwater management problems in both steady and unsteady states at any time step and simulation period. It is also more efficient in finding the optimal $\mathrm{Pa}$ reto front; Pareto optimality ranking and fitness sharing are the two necessary techniques to modify the fitness function of each population solution, by which a uniform distribution of the population solutions evolved with increase in the generation number. In this paper, the main objectives are to develop the (MOGA) with two additional techniques, Pareto optimality ranking and fitness sharing, that simultaneously maximize the pumping rate and minimize pumping cost. A compromise solution from a set of Pareto optimal solutions is also achieved to help the decision maker for Wadi El-Farigh, Egypt.

\section{Site description}

The study area lies in the western fringes of the Nile Delta, Egypt, between longitudes $30^{\circ} 00^{\prime}$ and $30^{\circ} 50^{\prime} \mathrm{E}$ and latitudes $30^{\circ} 00^{\prime}$ and $30^{\circ} 33^{\prime} \mathrm{N}$ (Fig. 1). It extends from $62 \mathrm{~km}$ (Cairo-Alex Highway) in the south to El-Alamein Desert Road at $126 \mathrm{~km}$ to the north, covering an area of 800,000 Fadden. It encompasses Wadi El-Farigh, Wadi ElNatrun and adjacent areas. The climate is characterized by a long hot summer and a short warm winter, low rainfall and high evaporation. 


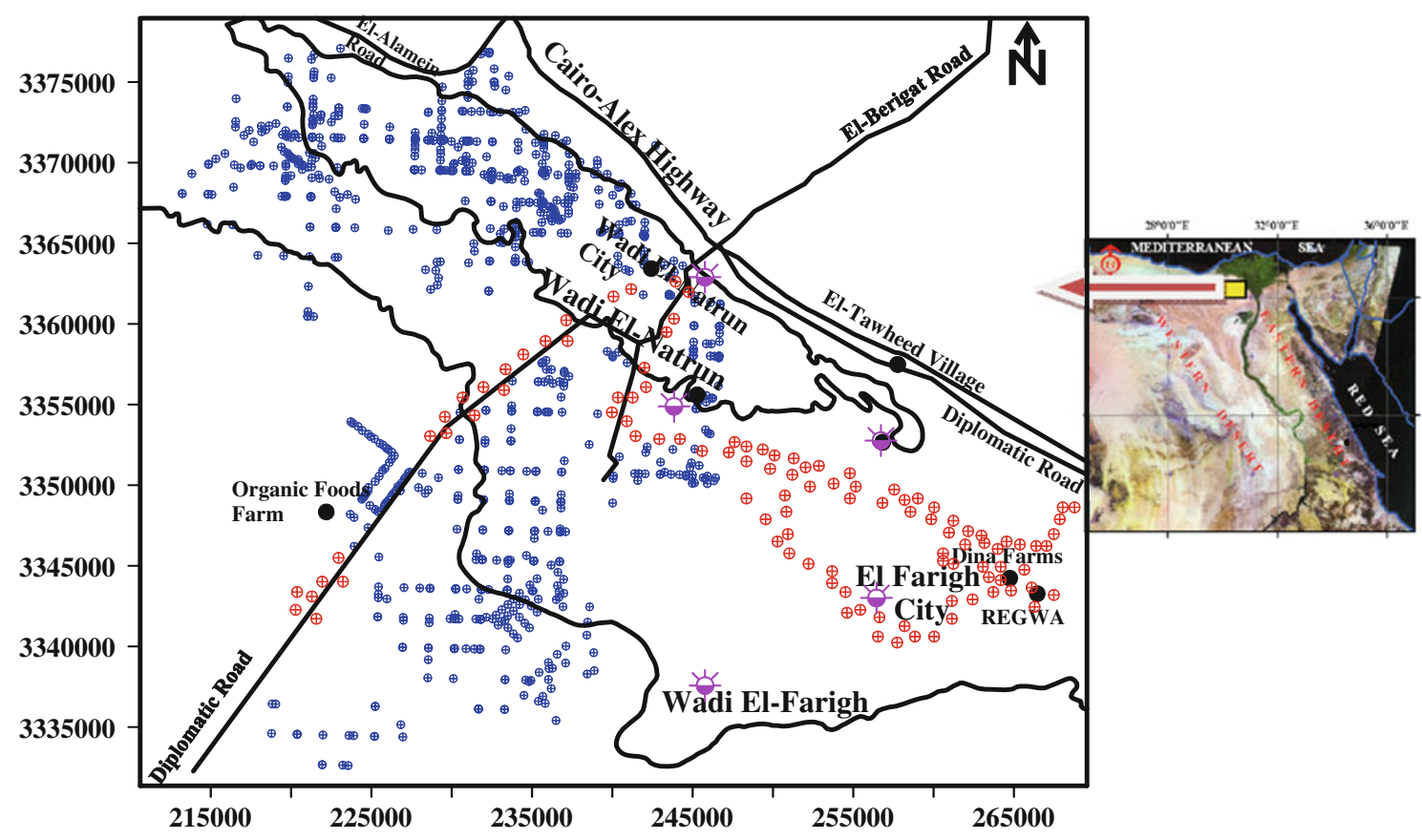

Opservation well $\oplus$ Productive well before $2006 \oplus$ Productive well after 2006

Fig. 1 Well location map of the study area

Geomorphological and geological setting

Shata et al. (1962), Said (1962), Omara and Sanad (1962), El-Fayoumy (1964), Sanad (1973), El-Ghazawi (1982), Abdel-Baki (1983) and El-Kashouty and Sabbagh (2011) studied the geomorphology and geology of the study area. They concluded that the study area comprises three geomorphological units. The Alluvial plains (young and old alluvial plains) are characterized by an average gradient of $0.1 \mathrm{~m} / \mathrm{km}$. The elevation varies from +12 to $+14 \mathrm{~m}$ for the young alluvial plains and between 60 and $20 \mathrm{~m}$ for the old alluvial plains. The lowest point in Wadi El-Natrun and Wadi El-Farigh depressions is -23 and $-4 \mathrm{~m}$, respectively. The structural plains (depressions, folded ridges and structural plateaus) which have an elevation that ranges between $110 \mathrm{~m}$ at Gebal Hamza and $200 \mathrm{~m}$ at Abu Roash (the ridges bounding Wadi El-Farigh). The tablelands are differentiated into Maryut tableland and marginal tableland. The sedimentary succession in the study area ranges in age from late tertiary which is differentiated into Oligocene at $400 \mathrm{~m}$, Miocene at $200 \mathrm{~m}$ and Pliocene at $150 \mathrm{~m}$ to Quaternary at $300 \mathrm{~m}$. The study area also is affected by a number of faults having NW-SE and NE-SW trends.

\section{Groundwater hydrology}

There are three main aquifers in the study area, namely, the Nilotic sand and gravel (Pleistocene aquifer), Wadi ElNatrun sand and clay (Pliocene aquifer) and El-Moghra quartizitic sand (Ahmed 1999; El-Sheikh 2000; Ibrahim 2000, 2005) (Fig. 2). The present study concentrates on the El-Moghra aquifer in Wadi El-Farigh (MAIWF), according to its high transmissivity and water quality.

The lateral and vertical distributions of the encountered aquifers as well as their inter-relationships are well illustrated through two cross sections as shown in Fig. 2. In this figure, the Pleistocene aquifer exists at the northeast part of the study area to the east of Wadi El-Natrun with thickness range of 65 to $75 \mathrm{~m}$. The Pliocene aquifer exists at Wadi El-Natrun depression with thickness of $50-70 \mathrm{~m}$. The MAIWF exists at Wadi El-Farigh depression to the south and west of Wadi El-Natrun having a thickness of about $100 \mathrm{~m}$. The basaltic sheets were detected along the southeastern part of the study area and are considered the base of the MAIWF and a marker bed separating the overlying Miocene aquifer and the underlying Oligocene aquifer. The faults play an important role in the connections between the different aquifers as well as the direct effect on the saturated zones. The depth to water ranges between 0 at the ground surface at Wadi El-Natrun lakes to $180 \mathrm{~m}$ from the ground surface to the west of Wadi ElNatrun. Generally, the depth to water increases from Wadi El-Natrun to the other directions. The general trends of the groundwater movement are from east to west, from northeast to southwest, from south to north and from southwest to northwest. The contour lines are closer around Wadi El-Natrun and reach its minimum level $-22 \mathrm{~m}$. This means Wadi El-Natrun depression is recharged from the 
Fig. 2 Panel diagram showing the different water bearing formations in the study area (after El Abd 2005)

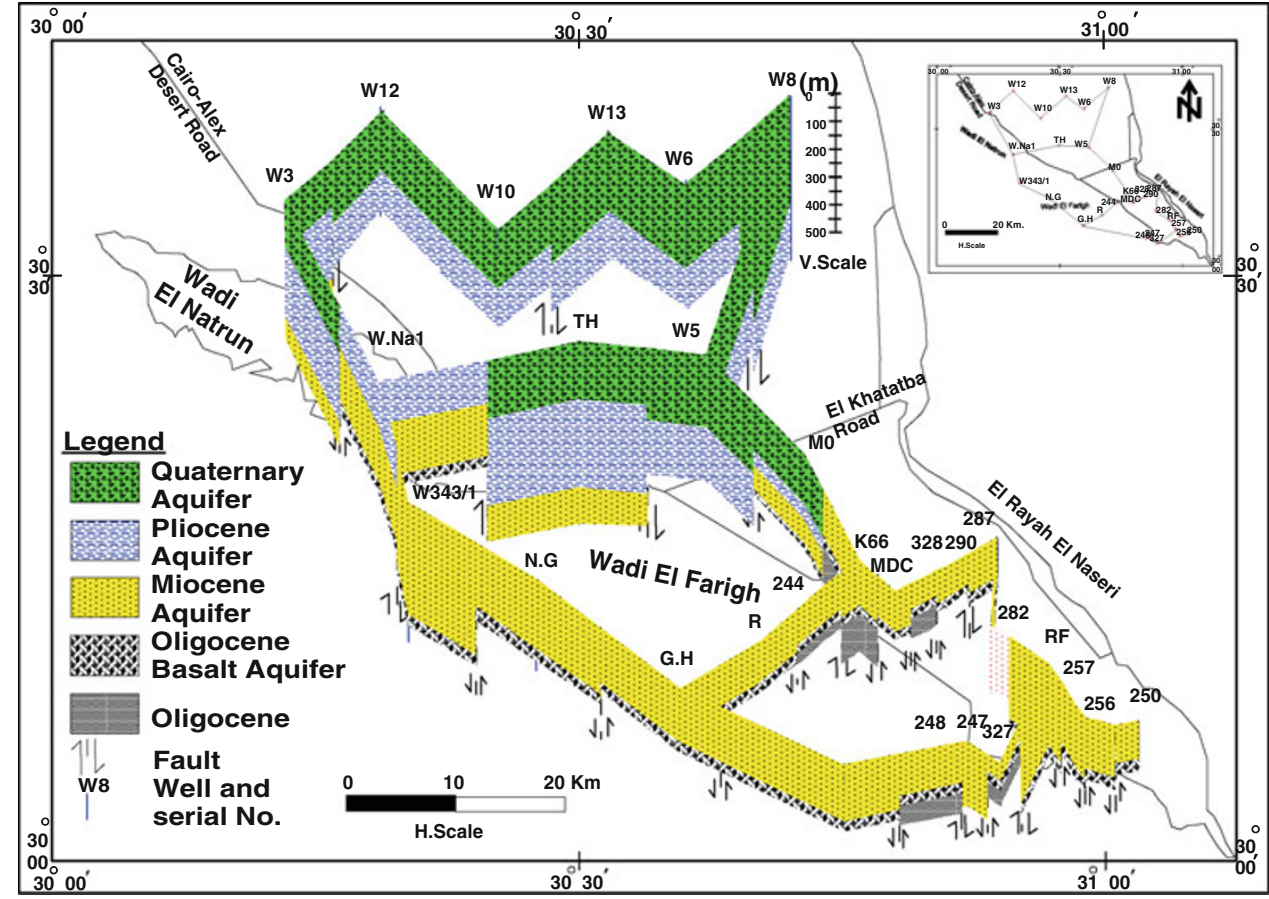

\begin{tabular}{llllll}
\hline $\begin{array}{l}\text { Source of data and } \\
\text { test location }\end{array}$ & $\begin{array}{l}\text { Saturated } \\
\text { thickness (m) }\end{array}$ & $\begin{array}{l}\text { Storativity } \\
S(-)\end{array}$ & $\begin{array}{l}\text { Transmissivity } \\
T\left(\mathrm{~m}^{2} \mathrm{~d}^{-1}\right)\end{array}$ & $\begin{array}{l}\text { Hydraulic } \\
\text { conductivity } \\
K\left(\mathrm{~m} \mathrm{~d}^{-1}\right)\end{array}$ & $\begin{array}{l}\text { Diffusivity } \\
(T / S)\left(\mathrm{m}^{2} \mathrm{~d}^{-1}\right)\end{array}$ \\
\hline $\begin{array}{l}\text { Ibrahim (2005)-DINA } \\
\text { Farms }\end{array}$ & $55.97-4,600$ & & 5,001 & $2.8-36.4$ & - \\
$\begin{array}{l}\text { Mostafa (1993)-Wadi } \\
\text { El-Farigh }\end{array}$ & & $1.2 \times 10^{-4}$ & 1,951 & - & $16,260,833$ \\
$\begin{array}{l}\text { Geirnaert (1992)-South } \\
\text { Wadi El-Natrun }\end{array}$ & - & - & - & 20 & - \\
\hline
\end{tabular}

Table 1 Hydraulic parameters of MAIWF (compiled from different authors)
REGWA 2006), registration of discharge, distribution of wells, proposed operating systems for both groundwater supply and reclaimed area beside recording depth to water for groundwater level changes.

The methodological approach used in this paper is based on the mathematical modeling techniques by applying two computer programs, visual MODFLOW and MOGA models. In the following, a brief description of these two methodologies is given.

\section{Visual MODFLOW model}

Visual MODFLOW is a 3D finite difference-based groundwater simulation system (McDonald and Harbaugh 1988). This model is capable of modeling time-dependent flow as well as mass and heat transport problems. The timedependent data that should be included into the FDM model have to be stored outside in database or GIS systems. The model describes groundwater flow of constant 
density under non-equilibrium conditions in a heterogeneous and anisotropic medium. To simulate the groundwater flow in MAIWF, it requires the definition of the conceptual model, the model domain with flow boundary conditions and the aquifer material properties.

\section{Conceptual model of MAIWF}

To enable simulating groundwater flow in MAIWF, the conceptual model of the MAIWF has been constructed. It is based on the geology and the petro physics of the Moghra formation. Its thickness is about $75 \mathrm{~m}$ in the northern portion, $150 \mathrm{~m}$ in some localities at Wadi El-Farigh, $250 \mathrm{~m}$ in Wadi El-Natrun and gradually increases northwestward with a maximum thickness of about $900 \mathrm{~m}$ at El Qattara depression (Omara and Sanad 1962) (Fig. 3, left). The basaltic sheets are separating the overlying MAIWF and the Daba'a shale Formation; it has variable thickness ranging between 20 and $30 \mathrm{~m}$ and is located at different vertical levels. The hydrogeologic system was concerned unconfined and confined of one layer type. The variations in the hydraulic conductivity are resulting from the variation in the saturated thickness through the flow section, whereas the variation in the transmissivity resulting from the change in the potentiometric level.

Model domain and boundary conditions

The simulation procedure was started by dividing the MAIWF domain into a suitable grid pattern on which all the input items are performed via input menus. The total surface area of the model domain reaches $3,600 \mathrm{~km}^{2}$ (60 km in length and $60 \mathrm{~km}$ in width). The computational grid for the aquifer domain in the study area is divided into 3,600 cells ( 60 columns and 60 rows). The dimension of the cell nodes reaches $1,000 \mathrm{~m}$ for the cultivated and reclaimed areas (Fig. 3, right).

The hydraulic conditions at the boundaries of the model domain are specified. Depending on the groundwater flow pattern in the MAIWF (the water table in 1991), the boundary conditions are represented by the outer boundaries which are chosen to be natural boundaries to the system. Based on the fact that the boundaries should be taken remote enough from the effect of well fields to be considered as constant head boundaries (Gad 2010), the constant head boundary of $4 \mathrm{~m}$ asl is assigned in the NWSE direction parallel to the general fault (F6) which separates MAIWF from the adjacent Pleistocene aquifer. In addition, the variable head boundary between -16 and $22 \mathrm{~m}$ asl is assigned in SW direction. Otherwise, no flow boundary prescribed the north western and south eastern boundaries (Fig. 3, right). The hydraulic heads and hydraulic conductance are assigned to boundary cells. These heads vary during the simulation process according to different stresses applied on the modeled area.

\section{Aquifer characteristics}

The input parameters for the MAIWF simulation include aquifer hydraulic parameters (permeability and storage

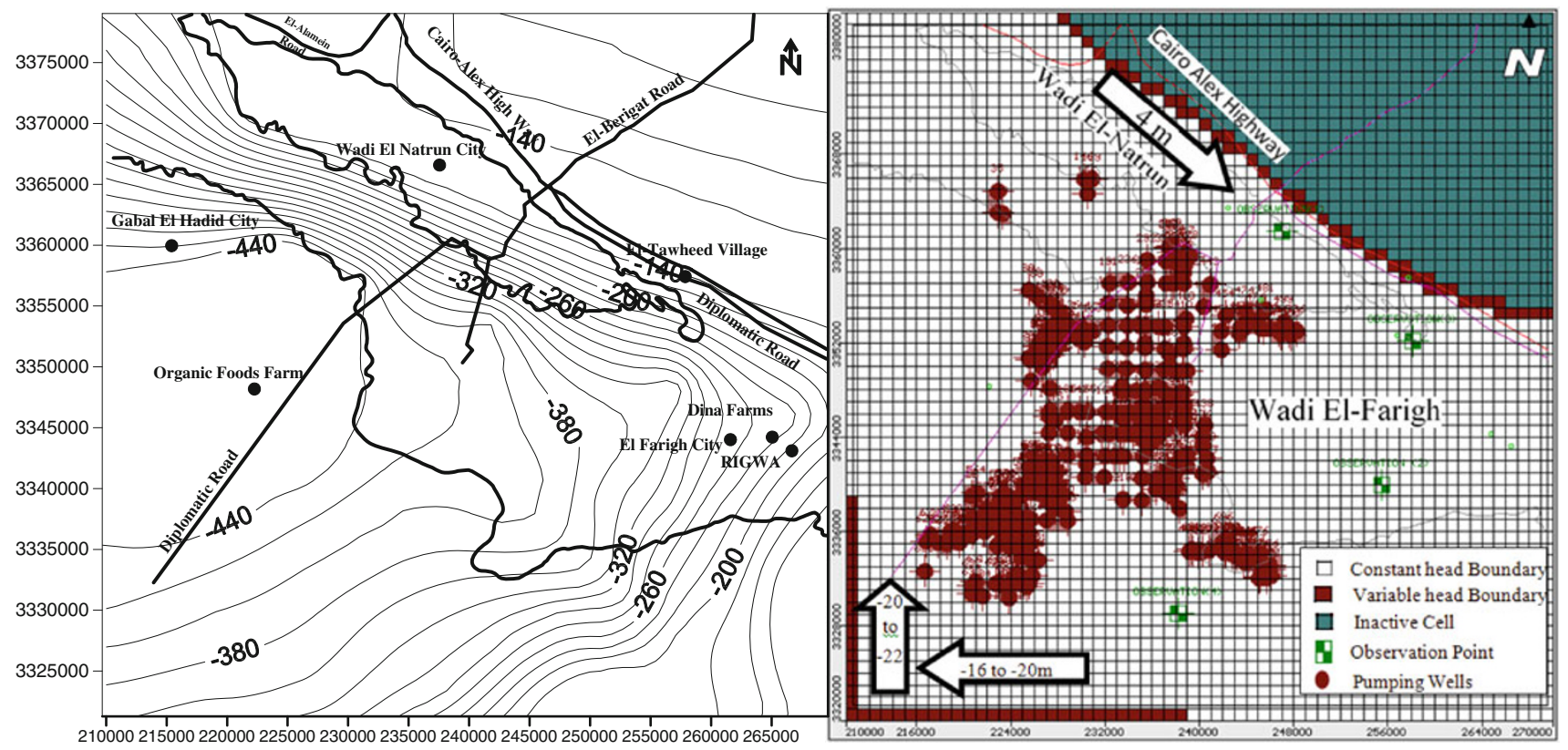

Fig. 3 Bottom elevation contour map (left map), model domain grid, location of observation wells and the boundary conditions (right map) of the simulated MAIWF 

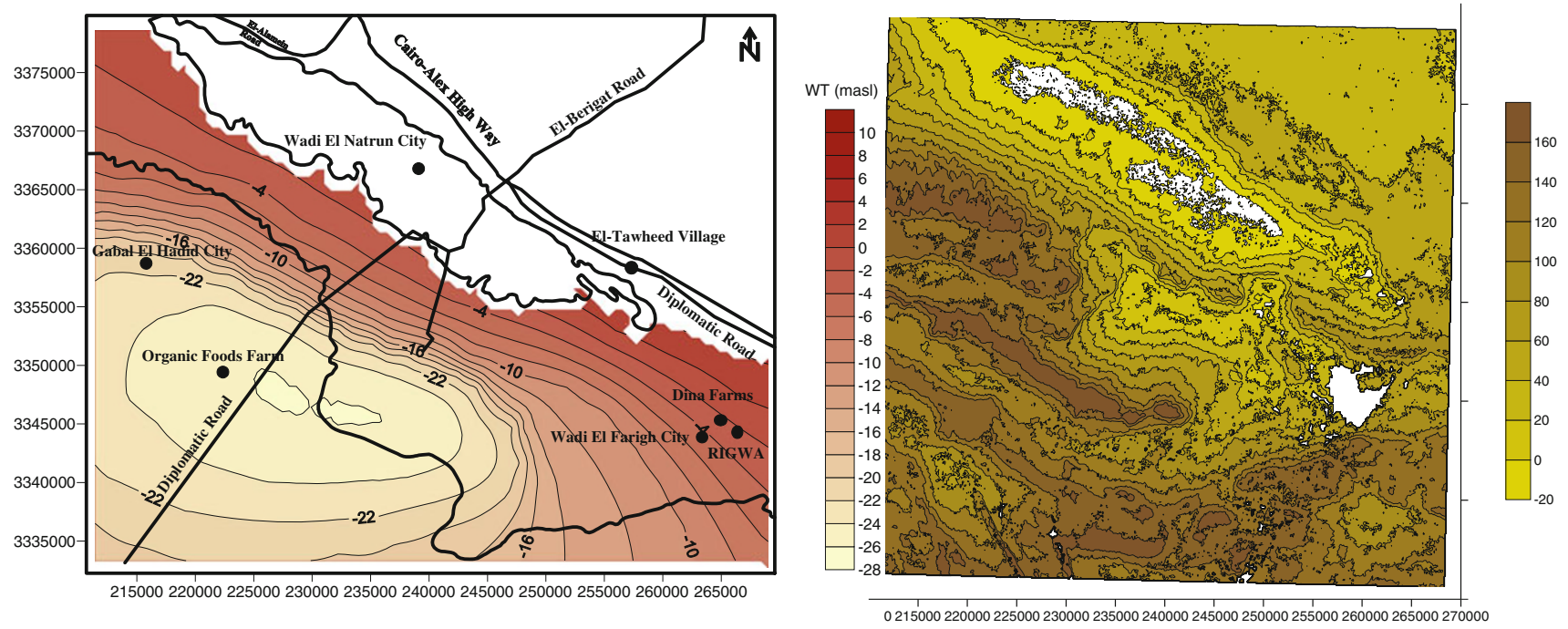

Fig. 4 Topographic contour map of the model domain extracted from digital elevation model (right) and equipotential contour map of the MAIWF at $1991($ left

coefficients), aquifer geometry (vertical and areal extent of the aquifer) and aquifer stresses (recharge and discharge). The hydraulic parameters of the MAIWF are given in Table 1.

Initial hydraulic head distribution and aquifer stresses

The United States Geological Survey (USGS) has converted the topographic maps of Egypt into digital elevation model (DEM) files. These files represent the land surface as a matrix (grid) of elevation values at a given space (resolution) apart. The 1:250,000 map series has been converted into 3 arc-second $(\sim 90 \mathrm{~m})$ resolution DEMs. DEM data are used in WMS to automatically delineate topography and ground elevation of the model domain (Fig. 4, left).

The recharge to the MAIWF may be from the Nile Delta area in the east and the Tahrir Province in the north as well as rainfall. The annual estimated rainfall in this arid area can be neglected. The discharge from the MAIWF may be from natural discharge represented in the evapotranspiration from Wadi El-Natrun depression and it is neglected. Artificial discharge is mainly through water extraction for the development projects and this is the source of discharge in the model domain. The total annual losses due to pumping were 207.7 million $\mathrm{m}^{3} /$ year and number of wells was 443 . The water level measurements through the bore piezometers in the model domain during 1991 are used to construct a contour map for the initial hydraulic head distribution (Fig. 4, left).

\section{Calibration and verification of the model}

The initial data of the hydraulic parameters such as hydraulic conductivity $(K)$ and specific yield $(S)$ have been entered into the model with initial values based on data collected after different authors in the study area. These data have very wide different ranges all over the modeled area (Table 1). Once these data are entered, the constructed model is allowed to run. If there is a convergence between the observed heads and calculated heads, an input data error is present which should be repaired time after time until running process goes successfully. This means that the model succeeds in computing the heads of the aquifer at every cell. As a result, a water level contour map namely calibrated head map is constructed using these calculated heads. The map plotted from the actual field head measurements differs from that of observed head map, as shown in Fig. 4. The relation between the calculated and the observed heads is checked every run from the calculated-observed head curve. The calibration process is very important to minimize the variance to a lower possible value. After changing many times the $K$ values, the variance between the observed and the calculated heads was minimized to $1.623 \%$ (Fig. 5).

\section{MOGA model}

The MOGA, used for the simulation of groundwater flow, is linked with genetic algorithm optimization by MODFLOW FORTRAN code. Figure 6 shows the flowchart for simulation-optimization model where FORTRAN program is used to link the simulation code and genetic algorithm. In this technique, two objectives are considered as follows:

(A) First objective, minimization of operation cost $\left(Z_{1}\right)$ : The cost objective demands for wells are operated in such a manner as to minimize the total cost. This essentially requires the identification for locations of wells as determination of their pumping rates satisfies the required water 

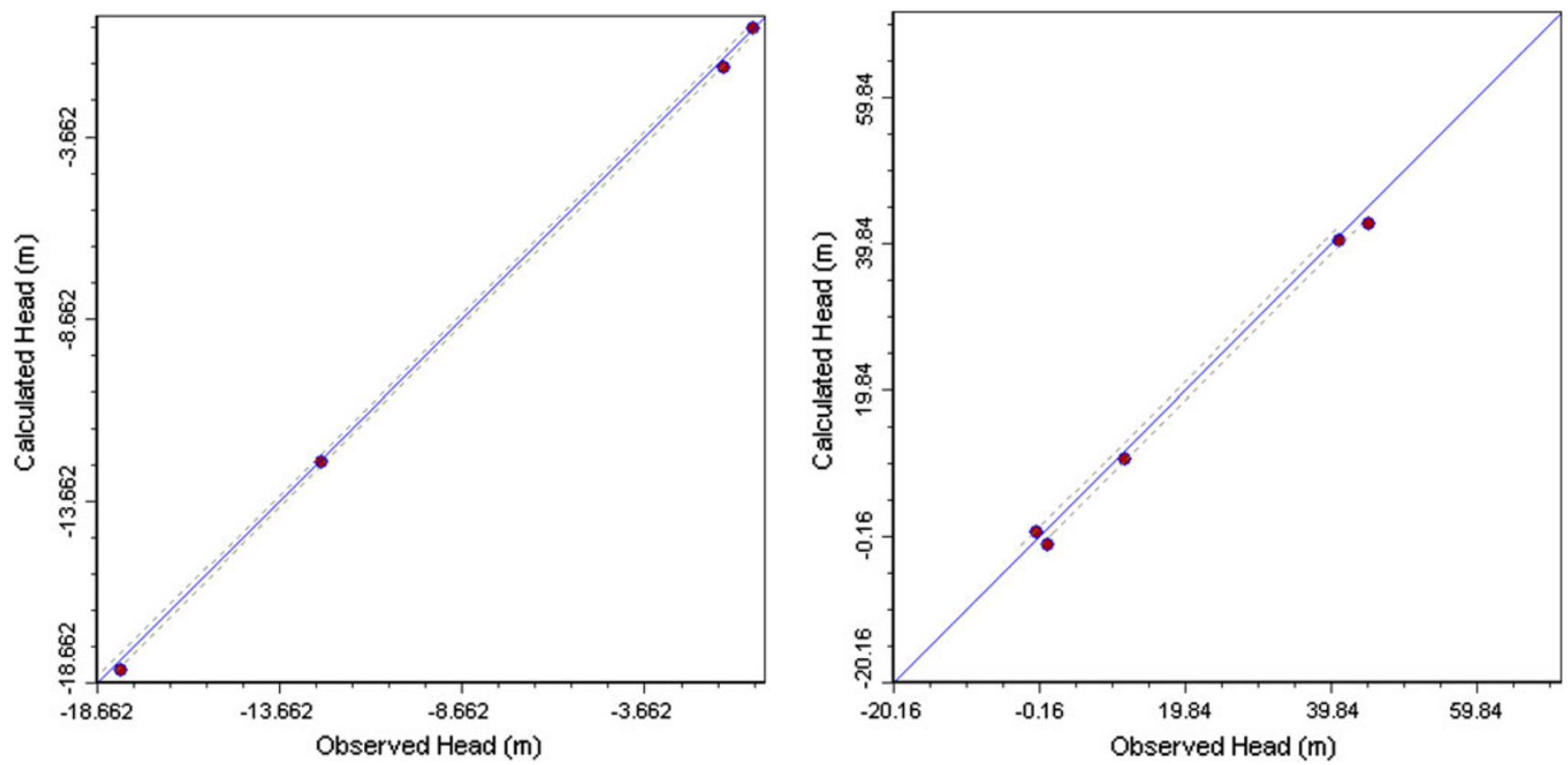

Fig. 5 The calculated head versus the observed head for steady (left map) and unsteady calibration (right map)

demand with the least possible cost. This objective is formulated as:

Min $\quad Z_{1}=\sum_{j=1}^{N_{\mathrm{w}}} C_{j} r_{j} Q_{j}$

where $N_{\mathrm{w}}$ is the number of potential pumping wells; $C_{j}$ the daily cost of pumping and transportation in monetary units, per unit volume per unit lift for location $j ; Q_{j}$ the pumping rate in cell $j,\left(j=1, \ldots, N_{\mathrm{w}}\right) ; r_{j}$ the pumping lift given by $\left(H-h_{j}\right) ; H$ the height of ground surface and $h_{j}$ is the head in pumping well $j$.

(B) Second objective, maximization of total pumping rates $\left(Z_{2}\right)$ : The studied area is characterized by inadequate water supply for both domestic and irrigation requirements. Then any surplus water from the domestic demand can be used for irrigation. Therefore, this objective seeks to maximize the amount of water which can sustainably be extracted from the groundwater aquifer. The objective of this study was to maximize the benefit function $Z$ with respect to pumping rate, $Q_{j}$ as design variable.

$\operatorname{Max} \quad Z=\sum_{j=1}^{N_{\mathrm{w}}} Q_{j}-P_{j}$

in which $N_{\mathrm{w}}$ is the total number of pumping wells and $P_{j}$ is the penalty.

Equations (1) and (2) are subject to three constraints: pumping constraint, drawdown constraint and water demand constraint.
(1) Pumping constraint $\left(Q_{j}\right)$ : The pumping rates at potential pumping wells in the water demand are constrained for values between some minimum $\left(Q_{j}^{\text {min }}\right)$ and maximum $\left(Q_{j}^{\max }\right)$. The permissible pumping rates were formed as follows:

$Q_{j}^{\min } \leq Q_{j} \leq Q_{j}^{\max } j=1, \ldots, N_{\mathrm{w}}$

For the GA simulation, this constraint can be easily satisfied by restricting the population space of the design variables within the above limits. Hence no special treatment is needed for this constraint.

(2) Drawdown constraint $\left(r_{j}\right)$ : This constraint normally means to protect the ecosystem by avoiding excessive drawdown. In this work, the drawdown constraints are formulated to avoid mining and formulated as follows:

$\sum_{j=1}^{N_{\mathrm{w}}} r_{j} \leq d_{i}$

in which $r_{j}$ is the drawdown at control point $i$ caused by a pumping rate from pumping well $j$ and $d_{i}$ is the permissible drawdown at control point $i$.

(3) Water demand constraint $\left(Q_{\mathrm{D}}\right)$ : The aquifer is considered the sole source of water. Therefore, the designed optimal pumping strategy must supply at least the minimum water demand. It is formulated as follows:

$\sum_{j=1}^{N_{\mathrm{w}}} Q_{j} \geq Q_{\mathrm{D}}$

where $Q_{\mathrm{D}}$ is the water demand. 
Discretization of optimization model

Multi-objective optimization extends optimization theory by permitting multiple objectives to be optimized simultaneously. In contrast with single-objective optimization problems, there may not exist a single solution that is optimal with respect to all objectives of the multi-objective optimization problem. Instead, there is a set of solutions that is superior to the rest of the solutions in the search space considering all objectives, and no solution in this set is absolutely better than the other solutions. This set is called the Pareto optimal set (Liu and Hammad 1997). Several methods for generating the Pareto optimal set of a multi-objective optimization problem have been proposed, such as weighting objectives, constraint approach, and goal programming (Konak et al. 2006). The basis of these methods is the transformation of the multi-objective optimization problem into a single-objective optimization problem by combining multi-objective into a single objective or transforming some objectives into constraints. The flowchart illustrating the MOGA implemented in the present study is shown in Fig. 6.

Three modules numbered in this figure are the main processes. These are (1) production of the initial generation and establishment of an initial Pareto optimal set, (2) application of MOGA techniques of Pareto optimality ranking and fitness sharing, and (3) reproduction by selection, crossover, and mutation operators and revision of the Pareto optimal set.

For each generation, MOGA firstly determines the fitness function of each population individual of the previous generation and then generates strings by selecting two parents on the basis of their fitness and reproducing them by crossover and mutation until the whole population is recreated. Finally, MOGA decodes and evaluates the strings of this new generation and revises the Pareto optimal set of the previous generation. This procedure is repeated many times until one of the following termination criteria is satisfied: (1) the maximum generation number is reached or (2) the convergence index is sufficiently small. Termination criterion (1) is necessary to prevent a run with excessively long time. Termination criterion (2) is an important criterion to check the convergence of the optimization procedure, as will be shown in the numerical example of the next section. In the numerical examples, the convergence of the preceding procedure was checked for several cases with different parametric values using a suggested convergence index.

Pareto optimality ranking and fitness sharing

Pareto optimality ranking suggested by Goldberg (1989) is rank-based fitness assignment method that takes into

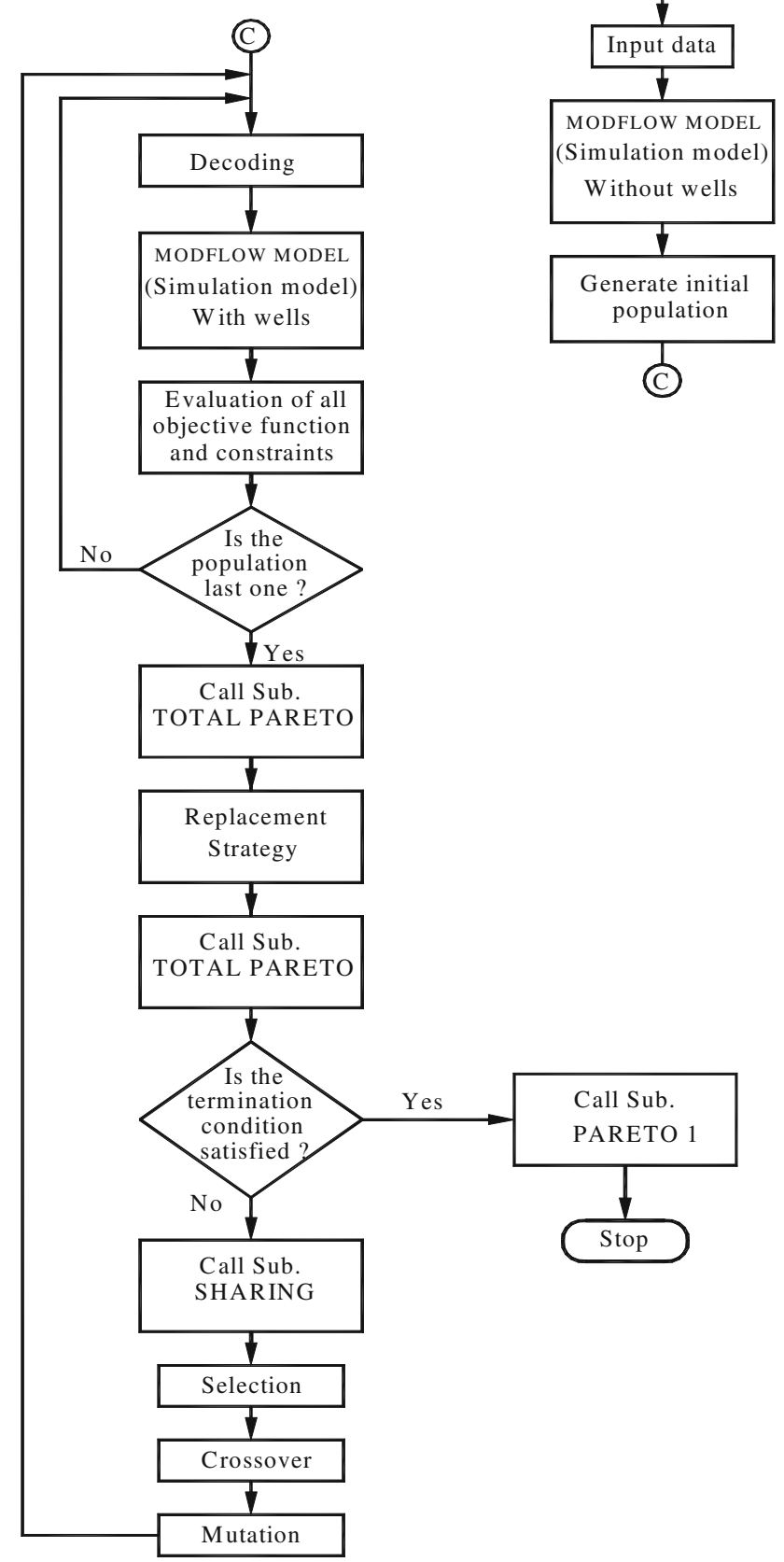

Fig. 6 Flowchart of MOGA model

consideration each of the different optimization objectives. To illustrate this method, an example of a ranked population of 20 solutions, plotted according to pumping cost versus average pumping rate, is shown in Fig. 7 (left). The superscripts of these individuals are the rank number and their subscripts represent indicates. All individuals in the current population are compared, and the non-dominated individuals are identified and assigned a rank of one, which is also the Pareto optimal set of this population. Then, these individuals of rank 1 are set apart, and the remaining individuals are 

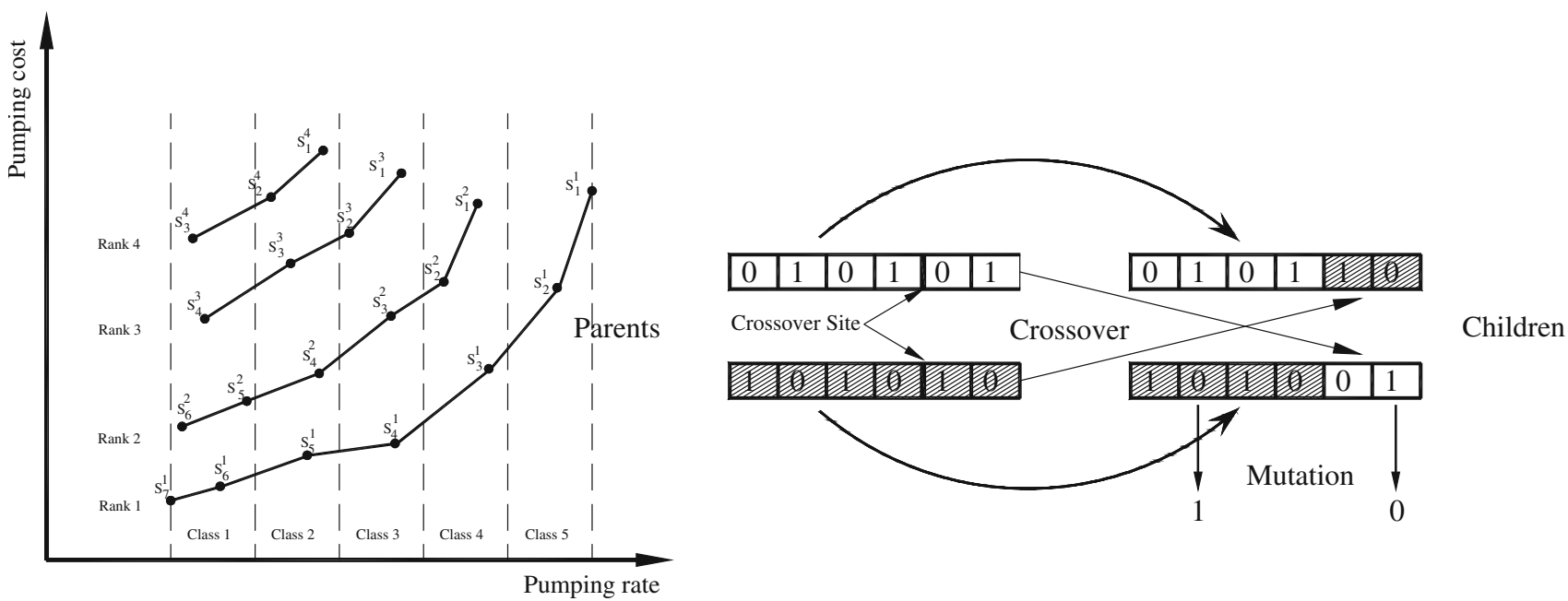

Fig. 7 Pareto optimality ranking and shared classes of population individuals (left) and crossover and mutation operators (right)

compared to select a new non-dominated set with a rank of two. This process continues until the entire population is ranked. The fitness function value of each individual is assigned according to its rank, as shown in Eq. (6).

$\mathrm{fit}(i)=\frac{1}{\operatorname{rank}(i)}$

where fit $(i)$ and rank $(i)$ are the fitness function and the rank number of individual number of individual $i$, respectively.

In addition, the fitness sharing used to divide the population into subpopulations of similar individuals is as shown in Fig. 7 (left). In a multi-objective optimization problem, fitness sharing is useful in stabilizing the multiple subpopulations that arise along with the Pareto optimal set and preventing excessive competition among distant population members. In this study, the pumping rate, one of the two objective functions, is divided into several intervals. Each solution is assigned to an interval, thus forming subpopulations classes of solutions. The sharing fitness function of a solution $i$ is taken as its fitness function divided by the number of solutions belonging to its class, that is,

shared fit $(i)=\frac{\operatorname{fit}(i)}{\operatorname{num}(i)}$

where shared fit $(i)$ is the shared fitness function of solution $i$ and num $(i)$ is the number of solutions in the class to which individual $i$ belongs. The shared fitness function of each solution replaces its fitness function as the selection criterion.

\section{Selection, crossover, and mutation}

GA technique was developed based on the Darwinian principle of the 'survival of the fittest' and the natural process of evolution through reproduction (Goldberg 1989). A solution for a given problem is represented in the form of a string, called "chromosome", consisting of a set of elements, called "genes", that hold a set of values for the optimization decision variables, in this study the pumping rate, $Q_{j}$ as design variable. The fitness of each chromosome is determined by evaluating it against an objective function. The chromosome represents a feasible solution for the problem under study. The length of the chromosome equals the number of variables. A gene value is real coding (actual values). The concept of GA is based on the initial selection of a relatively small population. Each individual in the population represents a possible solution in the parameter space. The fitness of each individual is determined by the value of the objective function, calculated from a set of parameters. The natural evolutional processes of reproduction, selection, crossover, and mutation are applied using probability rules to evolve the new and better generations. The probabilistic rules allow some less fit individuals to survive. As shown in Fig. 7 (right), crossover is introduced within every substring corresponding to one point, and the number of the crossover variables is the same as the number of points. The bitwise complement mutation operator changes one binary value to the opposite within every substring such as $0-1$ or $1-0$. The details of multipoint crossover and multipoint mutation can be found in Liu et al. (1996).

\section{Testing scenarios}

After completing the stage of calibration, the output of the first round is used to replace the initial condition with the condition of implementing the exploitation policies. The testing scenarios included three proposed water exploitation policies. The first scenario represents the 
existing policy in the MAIWF at 2006, with total pumping rate $569,020 \mathrm{~m}^{3} /$ day from 443 productive wells with an operating time of $10 \mathrm{~h} / \mathrm{day}$ and to predict the hydraulic head and drawdown from the year 2006 till the year 2050.

The second proposed scenario tests an increase in the pumping rate by $15 \%$. This increase in the pumping rate equals either an increase in the operating time per day from the same number of wells or an increase in the number of the productive wells to satisfy the increase in reclamation activities till the year 2050 .

The third proposed scenario studies the effect of the construction of a new water course, based on the governmental short-term action plan 2012-2017, on the groundwater regime in the MAIWF. This new canal will cross the north eastern parts of the model domain characterized by low groundwater potentiality. The action plan assumes duty of $3.85 \mathrm{MCM} /$ day based on the supplemented irrigation water requirements. Accordingly, 105 productive wells with total pumping rate of $176,780 \mathrm{~m}^{3} /$ day assume to be stopped, since the development in this area will depend mainly on surface irrigation.

In all these proposed scenarios, the optimal pumping rate and optimal pumping cost during the time steps of simulation are estimated from the predicted model outputs.

\section{Results and discussion}

The diffusivity $(T / S)$, which expresses the MAIWF potentiality, reads 16.2 MCM/day (western part of Wadi ElFarigh; Table 1). The northern part of the MAIWF has low groundwater potentiality as mentioned before. Accordingly, the location of the future reclamation activities in the northern part of MAIWF may not be in the proper site before construction of the new canal.

In addition, the results of the simulation process reveal that the implementation of the current development policy have serious impacts on the MAIWF storage. This is detected through the arbitrary five observation points in the model domain (Fig. 3, right map). Table 2 shows the predicted hydraulic head at the end of the simulation period (the year 2050) in the MAIWF's drilled wells for each locality by applying the three different proposed scenarios. It is noticed from the table that, under the exploitation strategy of $569,020 \mathrm{~m}^{3} /$ day (first proposed scenario), the predicted head points to $-11.52 \mathrm{~m}$ asl at Dina Farms locality (observation point 1 ), $-20.85 \mathrm{~m}$ asl at the organic food farms (observation point 2), $-27 \mathrm{~m}$ asl at south Wadi El-Natrun locality (observation point 3 ), $-18.63 \mathrm{~m}$ asl at west Dina Farms locality (observation point 4), and $-27.11 \mathrm{~m}$ asl at the central part of MAIWF (observation point 5) as shown in Table 2.

In general, the relatively low decline in the predicted hydraulic head in the southern part of the MAIWF compared with the other aquifer localities may attribute to the increase in aquifer thickness, increase in sand ratio and high lineaments density (Diab et al. 2002; El Abd 2005; GAD 2010). The results of the simulation process by applying the second proposed scenario (an increase in the daily pumping rate for all operating wells by $15 \%$ ) indicate that the predicted head at the year 2050 points to $-12.28 \mathrm{~m}$ asl in Dina Farms locality (observation point 1), $-22.62 \mathrm{~m}$ asl at the western part of MAIWF (observation point 2 at organic foods farms), $-29.01 \mathrm{~m}$ asl at the northern part of MAIWF, south Wadi El-Natrun (observation point 3), $-20 \mathrm{~m}$ asl at west Dina Farms locality (observation point 4) $-31.21 \mathrm{~m}$ asl at the central part of MAIWF (observation point 5) as shown in Table 2. These results are more or less comparable with the results of Youssef et al. (2012).

Under the exploitation strategy represented in the third proposed scenario by decreasing the number of productive wells by 105 wells conserving $176,780 \mathrm{~m}^{3} /$ day, the total pumping rate will reach $392,240 \mathrm{~m}^{3} /$ day. The proposed surface canal will feed the groundwater with an amount of $389,985 \mathrm{~m}^{3} /$ day. Under these conditions, the predicted hydraulic head values by the year 2050 will reach -11.03 , $-16.96,-24.55,-17.34$ and $-25.01 \mathrm{~m}$ asl, respectively.

In addition, the predicted groundwater flow direction in the MAIWF changes from east to west direction, as a general at the beginning of the simulation period, to the concentric direction toward the central part of the model
Table 2 The predicted hydraulic head in MAIWF at the observation points by applying different proposed scenarios

\begin{tabular}{lllll}
\hline $\begin{array}{l}\text { Observation } \\
\text { point no. }\end{array}$ & Location in MAIWF & \multicolumn{2}{l}{ Predicted head at the year 2050 (m asl) } \\
\cline { 3 - 5 } & & $\begin{array}{l}\text { First } \\
\text { scenario }\end{array}$ & $\begin{array}{l}\text { Second } \\
\text { scenario }\end{array}$ & $\begin{array}{l}\text { Third } \\
\text { scenario }\end{array}$ \\
\hline Point 1 & Eastern part (Dina Farms) & -11.52 & -12.28 & -11.03 \\
Point 2 & Western part (Organic food farms) & -20.85 & -22.62 & -16.96 \\
Point 3 & Northern part (South Wadi El-Natrun) & -27.28 & -29.01 & -24.55 \\
Point 4 & West Dina Farms & -18.63 & -20.00 & -17.34 \\
Point 5 & Central part & -27.11 & -31.21 & -25.01 \\
\hline
\end{tabular}


domain at the end of simulation period (the year 2050) (Fig. 8). This reflects that the upstream of surrounding high lands (Gabal El-Hadid City and Wadi El-Farigh City) acts as recharging areas to the flat areas of the MAIWF in the downstream (flat areas south Wadi El-Natrun in the central part of the MAIWF). The general decrease in the negative value of the groundwater table since pre-development at 1991 till the year 2050 may reflect the sharp groundwater decline problem in this aquifer as a result of over pumping.

The equipotential lines of the central part of MAIWF as shown in Fig. 8 are curved in an open trench with flow from all directions especially in the area of Gabal El-Hadid City (Fig. 8). This may be attributed to the concentration of wells in these parts with heavy uncontrolled pumping (more than 1,200 production wells). This open trench with flow from all directions appears at all time intervals related to the three proposed scenarios. But it divides into cone of depressions as a result of heavy pumping (Fig. 8). These cones of depression change the general groundwater flow direction from east-west to local flow direction of SW-NE as mentioned before.

Generally speaking, the predicted water table maps demonstrate the existence of a predominantly directed groundwater flow, slightly divergent from the main source of recharge. The MAIWF encompasses a large number of "flow domains" related to the larger and smaller high land areas that recharge the aquifer from southwest, east and west direction toward the central part of south Wadi ElNatrun area (Salem et al. 2010) (Fig. 8). The smaller flow systems consist of relatively low permeable deposits and constitute non-preferential zones for groundwater flow. The equipotential contour lines show concentric shape quite suddenly toward the central part of the MAIWF (south Wadi El-Natrun locality). Lower hydraulic gradients in this locality may attribute either to a lower flow density or to a lower transmissivity of the aquifer system. The conclusion is that the central part of the MAIWF is apparently thinner and/or is composed of other, less permeable deposits than other places (GAD and Abuel-Lohom 2011).

Moreover, the artificial recharge from the proposed canal assuming recharge rate of $2.739 \times 10^{-4} \mathrm{~m} /$ day through NW-SE aquifer boundary of $40 \mathrm{~km}$ length (third proposed scenario) will replenish the MAIWF storage and cause the potentiometric surface to more or less increase because the pumping rate is decreased as a result of stopping 105 productive wells with total pumping rate $176,780 \mathrm{~m}^{3} /$ day (Fig. 8 , lower). Also, the presence of the curvatures in the potentiometric surface passing through the southwestern part of the model domain as well as the change in its value from -12 to $-10 \mathrm{~m}$ asl may be attributed to the effect of local structures and predicted seepage from the artificial canal which accelerates the

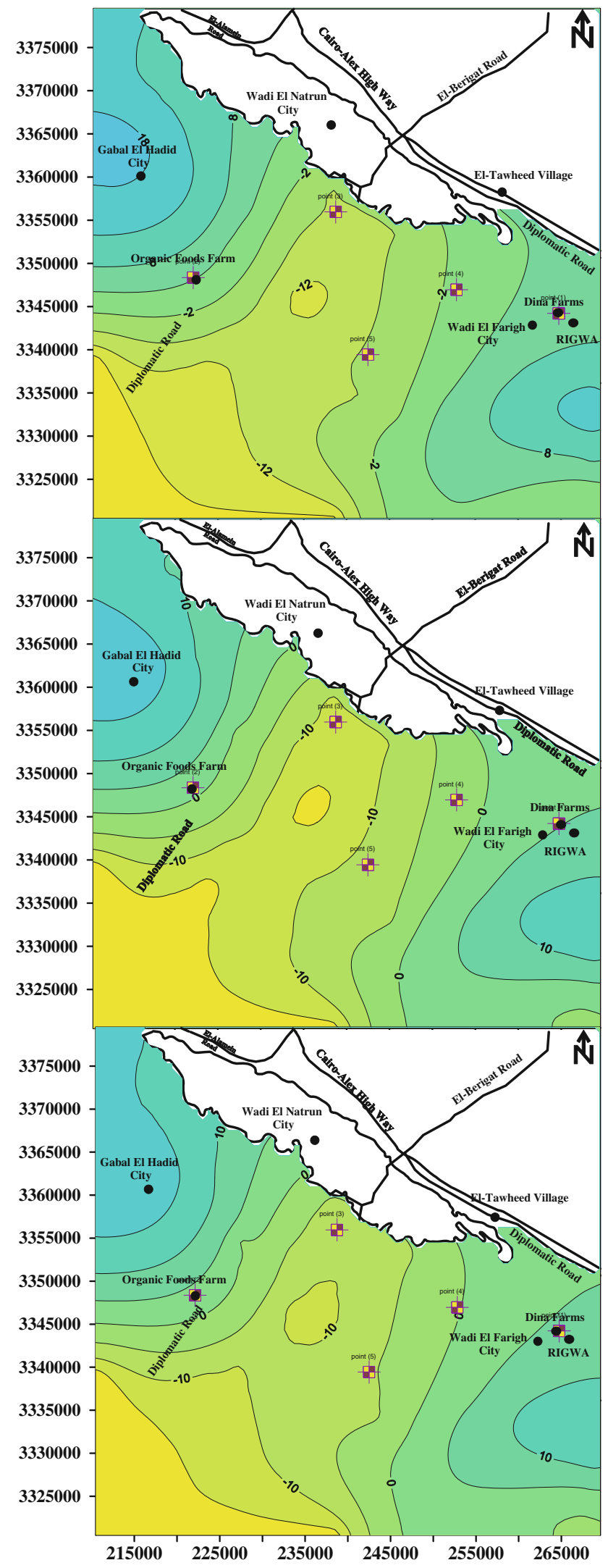

Fig. 8 Predicted head distribution maps of 1st (upper) 2nd (middle) and $3 r d$ (lower) scenarios at the end of simulation period (the year 2050) by applying MODFLOW software 
Fig. 9 The resulting convergence of MOGA model with fitness sharing

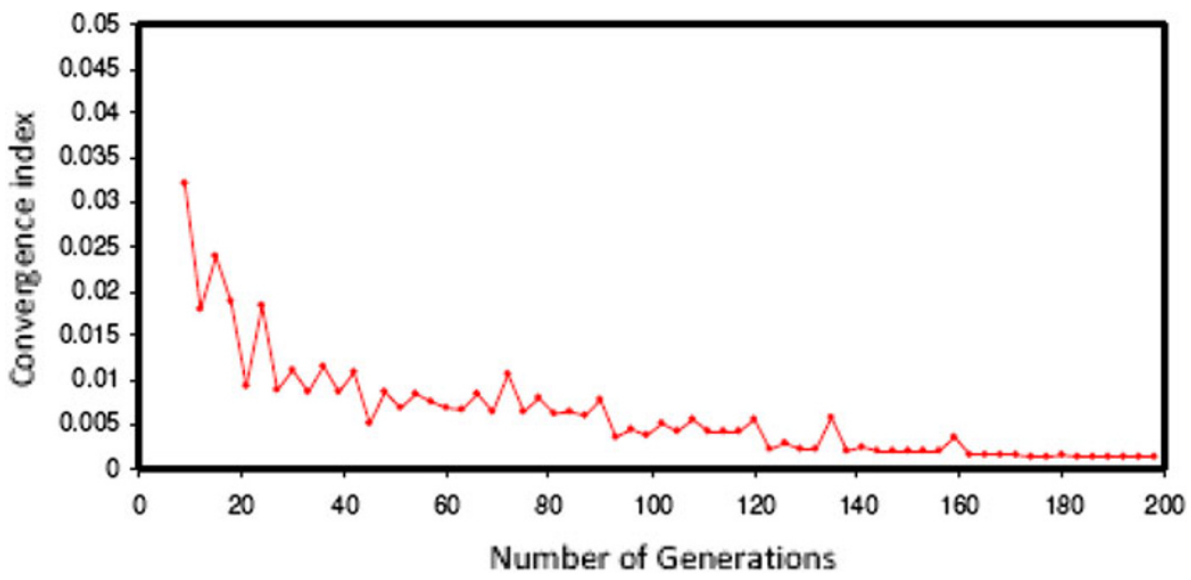

groundwater flow compared with the other localities. More studies are needed to assure this approach.

On the other side, the parameters of GA used as inputs to the applied MOGA model in this study are population size (200); number of generations (200); crossover ratio (0.6); mutation ratio (0.05); and uniform crossover. Convergence index for any generation equals the minimum distance between the current Pareto optimal solutions and the corresponding ones at the previous generation divided by number of current Pareto optimal solutions. The resulting convergence of the optimization process after checking according to the change in a convergence index with the number of generations is shown in Fig. 9. The code terminates as stated before, i.e., when the number of generation reaches its maximum value or the convergence index is less than or equal to 0.001 .

By applying the objective functions, Eqs. (1) and (2) and corresponding constraints (Eqs. 3-5) on these simulation results, MOGA model was run for the chosen time steps (the years 2015, 2020, 2025, 2030, 2035, 2040, 2050 and 2060) to predict the head maps and to estimate the optimal pumping rate with minimum operation pumping cost (Fig. 10; Table 3). It is noticed that, from Fig. 10, two cones of depression will appear in the cultivated areas in the model domain in the end of the simulation time with approximate diameter of 0.5 and $1 \mathrm{~km}$, respectively, under the current pumping rates. This may be attributed to the presence of relatively high sand-clay ratio in the aquifer lithology with low groundwater recharge rate characteristic of these aquifer localities. Otherwise, the middle part of the model domain is not affected by this phenomenon due to the effect of the great aquifer thickness and the presence of thin clay layers rather than the geologic structural impact (Salem et al. 2010; Gad et al. 2011; Youssef et al. 2012). Also, in the southwestern area, it is noted that the contour head is not affected by pumping during the simulation period. This may be attributed to the high values of hydraulic conductivity characterized to this locality (Youssef et al. 2012).

On the other side, the predicted optimized head distribution by applying first scenario ranges between $6 \mathrm{~m}$ asl and $22 \mathrm{~m}$ under sea level after 50 years of simulation, while it ranges from $6 \mathrm{~m}$ asl to $28 \mathrm{~m}$ under sea level after increasing the pumping rate by $15 \%$, according to the proposed second scenario, to become $349,258 \mathrm{~m}^{3} /$ day after the same period of simulation (Fig. 10). Moreover, the predicted optimized head distribution by applying third scenario ranges between $12 \mathrm{~m}$ asl and $26 \mathrm{~m}$ under sea level after 50 years of simulation, which reflects the effect of the new irrigation canal in recharging the groundwater system in the modeled area (Fig. 10).

In addition, the results of the final Pareto optimal solutions are shown in Fig. 10. Each point in this figure represents a possible solution for the problem, which contains pumping rate versus operation pumping cost. To determine the compromise solution among the set of Pareto optimal solutions shown in this figure, the code given by El-Beltagy et al. (2010) is again used. The values of the compromise solutions are presented in Table 3. From Table 3, it is noticed that as the optimal pumping rate in the MAIWF decreases, the optimal pumping cost increases at specific periods (the cost assumption is increased with $5 \%$ for every 5 years). Moreover, it is observed that the optimal pumping rate is decreased up to 30 years of simulation, while it is almost constant during the interval from 2030 up to 2060 . This may be attributed to the increase in the local groundwater recharge from the surrounding aquifer system outside the model area after the first 15 years of the simulation period till it reaches gradually to the natural balance by the end of the simulation period ( 50 years).

The resulting optimal pumping rate and the corresponding optimal cost range from $611,936.3 \mathrm{~m}^{3} /$ day to $576,129.8 \mathrm{~m}^{3} /$ day and $2.9-3.7$ million LE, respectively, applying the first scenario (Table 3). Moreover, the 

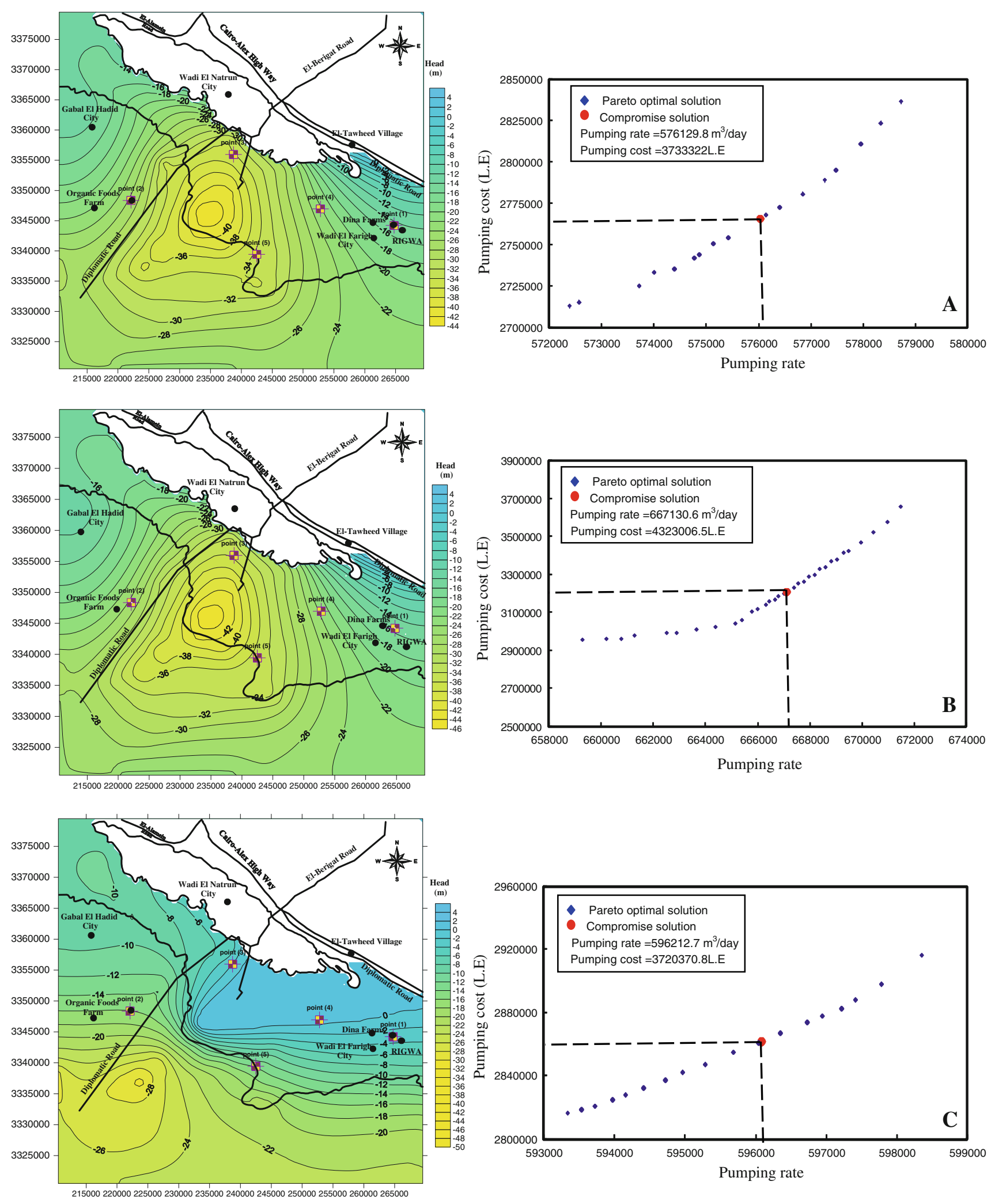

Fig. 10 Predicted head distribution map of the MAIWF at 2050, based on the optimal pumping rate by applying MOGA model (1st scenario upper map, 2 nd scenario middle map and 3 rd scenario lower map) 
Table 3 Compromise solution for optimal pumping rate and optimal pumping cost by applying MOGA model

\begin{tabular}{|c|c|c|c|c|c|c|}
\hline \multirow[t]{2}{*}{ Time interval (years) } & \multicolumn{2}{|c|}{ First scenario (existing policy) } & \multicolumn{2}{|c|}{$\begin{array}{l}\text { Second scenario (increase the } \\
\text { pumping rate by } 15 \% \text { ) }\end{array}$} & \multicolumn{2}{|c|}{$\begin{array}{l}\text { Third scenario (construction of new canal with } \\
2.1 \text { million } \mathrm{m}^{3} / \text { day) }\end{array}$} \\
\hline & $\begin{array}{l}\text { Pumping rate } \\
\left(\mathrm{m}^{3} / \text { day }\right)\end{array}$ & $\begin{array}{l}\text { Optimal } \\
\text { cost (LE) }\end{array}$ & $\begin{array}{l}\text { Pumping rate } \\
\left(\mathrm{m}^{3} / \text { day }\right)\end{array}$ & $\begin{array}{l}\text { Optimal } \\
\text { cost (LE) }\end{array}$ & $\begin{array}{l}\text { Pumping rate } \\
\left(\mathrm{m}^{3} / \text { day }\right)\end{array}$ & $\begin{array}{l}\text { Optimal } \\
\text { cost (LE) }\end{array}$ \\
\hline 5 & $611,936.3$ & $2,937,294$ & $708,592.9$ & $3,401,245.3$ & $633,267.2$ & $3,039,685.3$ \\
\hline 10 & $590,657.9$ & $2,976,916$ & $6,839,537$ & $3,447,125.2$ & 611,247 & $3,080,687.8$ \\
\hline 15 & $584,054.2$ & $3,083,807$ & $676,306.9$ & $3,570,899.9$ & $604,413.7$ & $3,191,304.6$ \\
\hline 20 & $578,918.3$ & $3,195,628$ & $6,703,595$ & $3,700,383.5$ & $599,098.6$ & $3,307,024.5$ \\
\hline 25 & $576,716.9$ & $3,321,889$ & $667,810.1$ & $3,846,587.7$ & $596,820.6$ & $3,437,687.3$ \\
\hline 30 & $5,764,234$ & $3,458,540$ & $667,470.7$ & $400,482,296$ & $596,516.7$ & $3,579,101.9$ \\
\hline 40 & $576,276.4$ & $3,595,966$ & 667,301 & $4,163,955.5$ & $596,364.7$ & $3,721,318$ \\
\hline 50 & $576,129.8$ & $3,733,322$ & $667,130.6$ & $4,323,006.5$ & $596,212.7$ & $3,720,370.8$ \\
\hline
\end{tabular}

resulting optimal pumping rate and the corresponding optimal cost by applying the second scenario of increasing the pumping rate by $15 \%$ ranges from $708,592.9 \mathrm{~m}^{3} /$ day to $667,130.6 \mathrm{~m}^{3} /$ day and $3.4-4.3$ million LE, respectively, while in case of third scenario, the resulting optimal pumping rate ranges from $633,267.2 \mathrm{~m}^{3} /$ day to $596,212.7 \mathrm{~m}^{3} /$ day and the corresponding optimal cost ranges from 3.0 to 3.7 million LE (Table 3).

The compromise solution among the set of Pareto optimal solutions for the three proposed scenarios are $576,129.8 \mathrm{~m}^{3} /$ day and 3,733,322 LE for the first scenario, $667,130.6 \mathrm{~m}^{3} /$ day and 4,323,006.5 LE for the second scenario and $596,212.7 \mathrm{~m}^{3} /$ day and 3,720,370.8 LE for the third scenario (Fig. 10).

In addition, the predicted head distribution maps of the MAIWF at 2050, based on the optimal pumping rate by applying MOGA model, reflect more details about the evolution of groundwater system under the proposed aquifer stresses (Fig. 10). The maps show more details with respect to the resulting cone of depression during the time of simulation. The predicted temporal and special variations of groundwater are more obvious and assure the impact of geomorphological and structural settings on the groundwater occurrences in MAIWF during the simulation period as discussed before.

\section{Conclusion and recommendations}

The sustainable development in MAIWF suffers from some hydrological problems especially groundwater depletion as a result of improper groundwater exploitation policies. Both over pumping and inadequate well locations are the main causes of this problem. A trial to mitigate this problem was carried out in this paper via predicting the change in groundwater levels in the MAIWF under different water exploitation polices by applying suitable groundwater flow model (MODFLOW). The model was calibrated in steady-state condition and unsteady-state condition based on the piezometric heads at 1992 and 2006.

The predicted head of the MAIWF is based on three different scenarios: current pumping of $569,020 \mathrm{~m}^{3} /$ day, increasing pumping rate by $15 \%$ and construction of new irrigation canal with discharge of 3.85 million $\mathrm{m}^{3} /$ day.

The results of the simulation process reveal that the implementation of the current development policy (first proposed scenario) have serious impacts on the MAIWF storage. It is noticed the predicted head points to $-11.52 \mathrm{~m}$ asl at Dina Farms locality and $-20.85 \mathrm{~m}$ asl at the organic food farms, $-27 \mathrm{~m}$ asl at south Wadi El-Natrun locality. The second proposed scenario indicates that the predicted head at the year 2050 points to $-12.28 \mathrm{~m}$ asl in Dina Farms locality, $-22.62 \mathrm{~m}$ asl at the western part of MAIWF at organic foods farms, $-29.01 \mathrm{~m}$ asl at the northern part of MAIWF, south Wadi El-Natrun, $-20 \mathrm{~m}$ asl at west Dina Farms locality and $-31.21 \mathrm{~m}$ asl at the central part of MAIWF. In the third proposed scenario, the predicted hydraulic head values at the year 2050 will reach $-11.03,-16.96,-24.55,-17.34$ and $-25.01 \mathrm{~m}$ asl, respectively.

A computer programming with FORTRAN language has been originally established to apply the principles of the MOGA for studying the groundwater resources management. In MOGA model, MODFLOW is linked with GA technique to establish a simulation optimization groundwater model. MOGA model is applied to the MAIWF to develop maximum pumping rate and minimum operation cost. Also the prediction of the future changes in both pumping rate and pumping operation cost is developed. Pareto optimality ranking and fitness sharing are the two necessary techniques to modify the fitness function of each population solution, by which a uniform distribution of the population solutions evolved with increase in the 
generation number. The Pareto optimal set at the final generation illustrates the relationship between the pumping rate and pumping operation cost. This relationship provides the decision makers with several candidate solutions. According to this relationship, the decision maker can work out the groundwater management considering both pumping rate and pumping cost.

Finally, the compromise solution has been chosen from a set of Pareto optimal solutions to help the decision maker. This compromise solution among the set of Pareto optimal solutions for the three proposed scenarios in MAIWF at year 2050 are optimal pumping of $576,129.8 \mathrm{~m}^{3} /$ day with optimal cost of 3,733,322 LE for the first scenario, optimal pumping of $667,130.6 \mathrm{~m}^{3} /$ day with optimal cost of $4,323,006.5 \mathrm{LE}$ for the second scenario and optimal pumping of $596,212.7 \mathrm{~m}^{3} /$ day with optimal cost of 3,720,370.8 LE for the third scenario.

The performance of the proposed MOGA model, when applied to the MAIWF under the available data, establishes its potential applicability to solve the complex groundwater management problems. The main advantage of the MOGA model is the possibility of linkage of the GA-based optimization model with an external flow simulation model. The relative ease and efficiency of this linkage, compared to the linkage using a classical nonlinear optimization technique, shall facilitate a solution to large scale and complex groundwater management problems. More researches in this field are recommended. It recommended a form of fitness sharing to enhance the Pareto GA in this area, where crowding in the Pareto optimal solutions is alleviated by decreasing the fitness of crowded individuals. It is also highly recommended to apply this new technique in all groundwater management strategies.

Open Access This article is distributed under the terms of the Creative Commons Attribution License which permits any use, distribution, and reproduction in any medium, provided the original author(s) and the source are credited.

\section{References}

Abdel-Baki AA (1983) Hydrogeological and hydrochemical studies on the area west of Rossetta branch and south El-Nasr canal. Ph.D. Thesis, Faculty of Science, Ain Shams University, Egypt, p 156

Ahlfeld DP, Heidari M (1994) Applications of optimal hydraulic control to groundwater systems. J Water Resour Plan Manage 120(3):350-365

Ahmed SA (1999) Hydrological and isotope assessment of groundwater in Wadi El-Natrun and Sadat City, Egypt. Ain Shams University, Cairo, p 237

Cheng R, Gen M (1998) "Compromise approach-based genetic algorithms for bicriterion shortest path problems." Technical report, Ashikaga Institute of Technology
Cieniawski SE, Eheart JW, Ranjithan S (1995) Using genetic algorithms to solve a multi-objective groundwater monitoring problem. Water Resour Res 31(2):399-409

Deb K (2001) Multi-objective optimization using evolutionary algorithms. John Wiley \& sons, Chichester

Diab MS, Gad MI, Abdel-Baki AA, El Sheikh AE (2002) Study the effect of new reclamation projects on the groundwater system in the area northwest wadi El-Natrun and south El-Nasr canal by using mathematical modeling. In: Proceedings of the 3rd International Conference of groundwater level control inside urbanized areas, Faculty of Engineering, Mansoura University pp 279-292

El Abd EA (2005) "Geological impact on the water-bearing formations in the area southwest Nile Delta, Egypt". Ph.D. Thesis, Faculty of Science, El Menufiya University, Shibin El Kom, Egypt, p 254

El-Beltagy E, Hegazy T, Grierson D (2010) "A new evolutionary strategy for Pareto multi-objective optimization." In: Proceedings of the 7th international conference on engineering computational technology, Civil-Comp Press, Scotland

El-Fayoumy IF (1964) Geology of groundwater studies in Wadi ElNatrun area. M.Sc. Thesis, Faculty of Science, Cairo University, Egypt, p 109

El-Ghazawi MM (1982) Geological studies of the Quaternary Neogene aquifers in the northwest nile delta. M.Sc. Thesis, Faculty of Science, Al-Azhar University, Cairo, Egypt, p 170

El-Kashouty M, Sabbagh A (2011) Distribution and immobilization of heavy metals in Pliocene aquifer sediments in Wadi El Natrun depression, Western Desert. Arab J Geosci 4(5-6):1019-1039

El-Sheikh AEA (2000) Hydrogeology of the area north and west of Wadi El-Natrun. MSc Thesis, Faculty of Science, Minufiya University

Fonseca C, Fleming PJ (1993) "Genetic algorithms for multiobjective optimization: formulation, discussion and generalization." In: Proceedings of the 5th international conference on genetic algorithms, pp 416-423

Frind EO (1982) Saltwater intrusion in continuous coastal aquiferaquitard systems. Adv Water Resour 5:89-97

Gad MI (2010) Towards a proposed policy of groundwater management in Nubian sandstone aquifer in Bir El-Shab area, South Western Desert, Egypt. J Fac Sci Ain Shamas University, Egypt 48:13-36

Gad MI, Abuel-Lohom N (2011) Water resources management in an arid area: estimation of groundwater depletion in Sana'a Basin, Yemen". In: Proceedings of the 1st International, renewable energy and technology conference (IRETC 1), Hurghada, Egypt

Gad MIE, El-Sheikh El-Osta MM (2011) Optimal management for groundwater of nubian aquifer in El-Dakhla depression, Western Desert, Egypt. J Water Resour Environ Eng 3(14): 393-409

Geirnaert W (1992) Composition and history of ground water in the western nile delta. J Hydrol 138:169-189

Goldberg DE (1989) Genetic algorithm in search, optimisation, and machine learning, Addison-Wesley, reading, MA

Horn J, Nafpliotis N, Goldberg DE (1994) "A niched Pareto genetic algorithm for multi-objective optimization" In: Proceedings of the 1st IEEE conference on evolutionary computation, IEEE world congress on computational intelligence, Orlando pp 82-87

Hsiao CT, Chang LC (2002) Dynamic optimal groundwater management with inclusion of fixed costs. J Water Resour Plan Manage 128(1):57-65

Hsu NS, Yeh WWG (1989) Optimum experimental design for parameter identification in groundwater hydrology. Water Resour Res 25(5):1025-1040 
Ibrahim SM (2000) Groundwater hydrology of El-Khatatba area and its vicinities, West Nile Delta, Egypt M.Sc. Thesis, Faculty of Engineering, Ain Shams University, Cairo, p 124

Ibrahim SM (2005) Groundwater resources management in Wadi ElFarigh and its vicinities for sustainable agricultural development. $\mathrm{Ph}$. D. Faculty of engineering, Ain Shams University, Cairo

Konak A, Coit DW, Smith AE (2006) Multi-objective optimization using genetic algorithms: a tutorial. Reliab Eng Syst Saf 91:9921007

Liu C, Hammad A (1997) Multi-objective optimization of bridge deck rehabilitation using a genetic algorithm. Micro comput Civ Eng 12:431-443

Liu C, Hammad A, Itoh Y (1996) "Cost optimization of bridge maintenance using genetic algorithm", In: Proceedings of the 15th IABSE congress, Copenhagen pp 457-462

McDonald MG, Harbaugh AW (1988) A modular three-dimensional finite-difference ground-water flow model-MODFLOW. US Geological Survey technique of water resources investigations, Book 6, Denver, Colorado

Moharram SH, GAD MI, Saafan TA, Khalaf SI (2011) Optimal groundwater management using genetic algorithm in El-Farafra Oasis, Western Desert, Egypt. Water Resour Manage. doi: 10.1007/s11269-011-9865-3

Mostafa NE (1993) Hydrogeological and hydro-studies on Wadi ElFarigh area, Western Desert, Egypt M.Sc. Thesis, Faculty of Science, El-Minoufiya University, Shibin El-Kom, p 132

Omara SM, Sanad S (1962) Rock stratigraphy and structural features of the area between Wadi El-Natrun and the moghra depression, Western Desert, Egypt. Geol J B 16:45-73

Park CH, Aral MM (2003) Multi-objective optimization of pumping rates and well placement in coastal aquifers. J Hydrol 290:80-99

Reading MA Goldberg DE, Richardson J (1987) "Genetic algorithms with sharing for multimodal function optimization." In: Grefenstette JJ, editor. Genetic algorithms and their applications: Proceedings of the 2nd international conference on genetic algorithms, Morgan Kaufmann, San Mateo p 41-49

REGWA General company for research and groundwater (2006) Composite well logs. Internal reports. Ministry of agriculture and land reclamation
Richardson JT, Palmer MR, Liepins G, Hilliard M (1989) "Some guidelines for genetic algorithms with penalty functions." In: Proceedings of the 3rd international conference on genetic algorithms, Morgan Kaufman, San Mateo, pp 191-197

Ritzel BJ, Eheart JW, Ranjithan S (1994) Using genetic algorithms to solve a multiple objective groundwater pollution containment problem. Water Resour Res 30(5):1589-1603

Saafan TA, Moharram SH, GAD MI, Khalaf S (2011) A multiobjective optimization approach to groundwater management using genetic algorithm. J Water Resour Environ Eng 3(7): 139-149

Said R (1962) The geology of Egypt. El-Sevier, Amesterdam

Salem BB, Gad MI, King CM (2010) Report to the international project on groundwater and human security case studies (GWAHS-CS): beni salama case study. United Nations University, Egypt

Sanad S (1973) Geology of the area between Wadi El-Natrun and moghra depression. Ph.D. Thesis, Faculty of Science, Assuit University, Assuit, p 184

Schaffer JD (1985) "Multiple objective optimization with vector evaluated genetic algorithms." In: Proceedings of the 1st international conference of genetic algorithms, Pittsburgh, pp 93-100

Shafike NG, Duckstein L, Maddock T (1992) Multi-criterion analysis of groundwater contamination management. Water Resour Bull 28(1):33-43

Shata AA, Pavlov M, Saad KF (1962) Preliminary report on geology, hydrogeology and groundwater hydrology of Wadi El-Natrun and adjacent areas. Internal Report Desert Institute, Cairo, p 159

Srinivas N, Deb K (1994) Multi-objective function optimization using non-dominated sorting genetic algorithms. Evol Comput 2(3): 221-248

Youssef T, GAD MI, Ali MM (2012) Assessment of groundwater resources management in Wadi El-Farigh area using MODFLOW. IOSR J Eng (IOSRJEN) 2(10):69-78 